\title{
Manajemen Krisis Satgas Penanggulangan Bencana PT. Banten Wet Java Tourism Development
}

Indonesian Journal of Tourism and Leisure, 2021
Vol. 02 (2), 76-95
(C) The Journal, 2021
DOI: $10.36256 /$ ijtl.v2i2.157
https: / / journal.lasigo.org/index.php/IJTL
Article History
Received: July $13^{\text {th }}, 2021$
Revised: September $2 t^{\text {th }}, 2021$
Accepted: October $9^{\text {th }}, 2021$

\section{Elsi Nurfauzi}

Universitas Serang Raya, Indonesia

nurfauzi.elsi@gmail.com

\section{Annisarizki}

Universitas Serang Raya

annisarizzkii@gmail.com

\section{Siska Mardiana}

Universitas Serang Raya

mardiana.siska@yahoo.com

\begin{abstract}
The purpose of this study was to determine the crisis management of PT. Banten West Java Tourism Development's post-tsunami disaster management task force. The theory used was situational of the public, using a qualitative approach with the case study method. The data collection techniques used were non-participant observation, semi-structured interviews and postdisaster documentation. tsunamis. The results of the study explained that the public focused on disasters, so the disaster management task force planned by forming a special communication team and Media Center, then working with Perum Damri Serang and the Central BMKG, as well as installing the Earthquake Early System (EEWS). Communication actions carried out by making Events and reposting Testimonials from Celebrity Endorsments. Planning and communication actions taken, to attract the public as tourists visiting for vacation in Tanjung Lesung without any sense of trauma followed by interesting events. The novelty in this study focuses more on the private sector PT Banten West Java Tourism as the main management of the Tanjung Lesung tourist area.
\end{abstract}

Keywords: Crisis management; Public Relations; Tanjung Lesung Tourism; Disaster Management Task Force.

\begin{abstract}
ABSTRAK
Tujuan penelitian ini untuk mengetahui manajemen krisis satgas penanggulangan bencana PT Banten West Java Tourism Development pasca tsunami 2018. Teori yang digunakan situasional of public, menggunakan pendekatan kualitatif dengan metode studi kasus. Teknik mengumpulkan data yang digunakan adalah observasi nonpartisipan, wawancara semi terstruktur dan dokumentasi pasca bencana tsunami. Hasil penelitian menjelaskan publik fokus pada saat bencana, maka perencanaan satgas penanggulangan bencana dengan membentuk tim komunikasi khusus dan Media Center, kemudian bekerja sama dengan perum damri Serang dan BMKG Pusat, sekaligus pemasangan Earthquake Early System (EEWS). Tindakan komunikasi
\end{abstract}


yang dilakukan dengan membuat event-event dan repost Testimoni dari para Celebrity Endorsment. Perencanaan dan tindakan komunikasi yang dilakukan, untuk menarik kembali publik sebagai wisatawan berkunjung untuk berlibur di Tanjung Lesung tanpa ada rasa trauma diikuti eventevent yang menarik. Kebaruan dalam penelitian ini lebih berfokus kepada sektor swasta PT Banten West Java Tourism sebagai pengelolaan utama kawasan wisata Tanjung Lesung.

Kata Kunci: Manajemen Krisis; Public Relations; Wisata Tanjung Lesung; Satgas Penanggulangan Bencana.

\section{Pendahuluan}

Pariwisata Tanjung Lesung merupakan Kawasan Ekonomi Khusus (KEK) yang dikelola oleh perusahaan swasta, yaitu PT. Banten West Java Tourism Development atau sering di sebut PT. BWJ. Kawasan pariwisata tanjung lesung merupakan kawasan wisata unggulan yang dimiliki Kabupaten Pandeglang, Provinsi Banten. Sabtu 22 Desember 2018 Kawasan Ekonomi Khusus Tanjung Lesung menjadi salah satu wilayah yang terkena bencana alam Tsunami yang diakibatkan oleh aktivitas vulkanik anak Krakatau yang memicu longsor dan menyebabkan Tsunami di Selat Sunda (Meilani \& Hardjosoekarto, 2020).

Pariwisata dikenal sebagai salah satu sektor penyumbang devisa terbesar bagi negara karena merupakan industri kompleks yang mampu memberikan pengaruh besar terhadap berbagai aspek kehidupan (Anggarani\& Aida, 2018:184). Wisata Tanjung Lesung turut menghidupi ekonomi masyarakat dan para pelaku wisata lainnya yang ada di sekitaran kawasan ekonomi khusus Tanjung Lesung. Namun bencana Tsunami 2018 telah membuat penurunan jumlah kunjungan wisatawan ke Tanjung Lesung, dimana pada enam bulan pertama pasca Tsunami kunjungan wisatawan ke Tanjung Lesung menurun sampai $100 \%$. Kondisi ini juga berdampak pada pendapatan para pelaku wisata lainnya juga yang berada di sekitar Tanjung Lesung. Bencana alam Tsunami yang melanda kawasan Tanjung Lesung menyebabkan lumpuhnya sektor pariwisata di Tanjung Lesung membawa PT. Banten West Java Tourism Development sebagai pengelola utama pariwisata Tanjung Lesung ke dalam masa krisis. Dalam kondisi bencana, informasi yang disampaikan oleh media kepada publik memiliki pengaruh yang penting dalam pengelolaan krisis (Fauzi, 2020:20).

Penurunan jumlah kunjungan wisatawan ke Tanjung Lesung pasca Tsunami 22 Desember 2018. Kunjungan wisatawan Tanjung Lesung tahun 2017 sampai dengan 2019 mengalami penurunan jumlah kunjungan di tahun 2019 yaitu pasca Tsunami 22 Desember 2018 di objek wisata Tanjung Lesung. November 2018 sebelum terjadinya bencana alam Tsunami jumlah kunjungan wisatawan ke Tanjung Lesung mencapai 806.056 kunjungan, sedangkan pada bulan November tahun 2019 pasca bencana alam tsunami kunjungan wisatawan ke Tanjung Lesung hanya 510.458 kunjungan wisatawan, sehingga hal tersebut dapat dikatakan bahwa Tanjung Lesung mengalami penurunan jumlah kunjungan wisatawan pasca Tsunami 22 Desember 2018.

Selain penurunan jumlah pengunjung, tsunami Tanjung Lesung juga telah memberikan rasa trauma yang cukup besar kepada masyarakat sekitar maupun masyarakat untuk berwisata pantai, sehingga menimbulkan stigma di masyarakat tentang berwisata pantai menjadi tidak aman. Hal ini pun diperkuat dengan berbagai pemberitaan yang muncul di media-media online terkait trauma yang dialami masyarakat pasca tsunami 22 Desember 2018, seperti pemberitaan yang diterbitkan oleh@pikiranrakyat.com (Pikiran-Rakyat.com, 2019): dengan tajuk berita "Masih Trauma Tsunami, Kunjungan ke Pantai Turun 60 Persen" pada pemberitaan tersebut Kabid Destinasi Wisata pada Dinas Pariwisata Provinsi Banten, Paundra Bayu Ajie mengatakan jumlah kunjungan wisatawan pada libur lebaran tahun 2019 ke sejumlah pantai di Banten hanya menembus angka 349.299 orang, jumlah ini turun hingga 60 persen dibanding tahun sebelumnya 
yang mencapai 1 juta kunjungan, hal ini imbas dari peristiwa bencana alam tsunami yang menerjang perairan Selat Sunda pada akhir tahun 2018. Pemberitaan trauma pasca tsunami Selat Sunda juga di terbitkan oleh Viva.co.id (2019) dengan tajuk berita "Satu Tahun Tsunami Selat Sunda, PHRI: Wisatawan Masih Trauma" pada pemberitaan tersebut Ketua Persatuan Hotel dan Restoran Indonesia (PHRI) Kabupaten Pandeglang Widiasmanto mengatakan masyarakat masih trauma dengan peristiwa yang menewaskan ratusan orang dan ribuan orang luka-luka, Widiasmanto mengemukakan sebelum terjadinya tsunami Selat Sunda atau tahun lalu, hunian hotel di Kabupaten Pandeglang mencapai 80 sampai 100 persen saat mendekati malam tahun baru, sementara saat ini pasca tsunami masih dibawah 50 persen.

Penyelenggaraan Public Relations pasca bencana jika tidak dikelola dengan baik juga berdampak secara luas di masyarakat terutama korban bencana yang mengalami trauma kegelisahan, tidak tahu arah dan tujuan hidup, serta kekhawatiran dan ketakutan yang berkepanjangan (Hasan, 2012:69). Kesadaran akan pentingnya komunikasi dalam penanganan bencana semakin tinggi belakangan ini, salah satu titik penting yang menjadi perhatian terkait komunikasi dalam bencana adalah masalah ketidakpastian (Rudianto, 2015:54). Pentingnya mengembangkan sistem mitigasi menjadi tanggung-jawab pengelola destinasi wisata, hal tersebut sebagai upaya dalam menghindari ketidaksesuaian ekspektasi yang diterima wisatawan dan meningkatkan persepsinya terhadap destinasi pariwisata (Wulung, 2020:2884). Pada saat terjadinya bencana alam tsunami yang menerjang kawasan wisata Tanjung Lesung dan menyebabkan krisis pasca tsunami PT. Banten West Java Tourism Development mengalami kekosongan jabatan pada posisi Public Relations, sehingga PT. Banten West Java Tourism Development membentuk tim khusus yang diberi nama satgas penanggulangan bencana untuk mengatasi krisis yang timbul pasca tsunami dan upaya pemulihan wisata Tanjung Lesung pasca tsunami yang menerjang kawasannya.

Peran satgas penanggulangan bencana sebagai tim khusus yang dibentuk oleh PT. Banten West Java Tourism Development dalam masa krisis pasca tsunami 22 Desember 2018 menjadi sangat penting, bagaimana pihak Satgas penanggulangan bencana PT, Banten West Java Tourism Development merespon krisis, melakukan perencanaan krisis, bagaimana proses komunikasi, bagaimana menyediakan dan mengontrol arus informasi selama masa krisis, dan segala upaya yang dilakukan untuk keluar dari masa krisis.

Agar PT. Banten West Java Tourism Development dapat melewati masa krisis pasca Tsunami 22 Desember 2018, tim khusus Satgas penanggulangan bencana memiliki tanggung jawab untuk dapat mengambil keputusan-keputusan yang cepat dan tepat, dengan tujuan untuk membawa PT. Banten West Java Tourism Development keluar dari masa krisis pasca Tsunami 22 Desember 2018. Krisis sendiri dapat terjadi tanpa pandang bulu, artinya krisis dapat melanda berbagai organisasi atau perusahaan baik besar maupun kecil (Butterick, 2014:72). Menjelaskan krisis dalam suatu bisnis terjadi ketika nilai penjualan jatuh dan keuntungan berkurang. Maka apa yang dialami oleh PT. Banten West Java Tourism Development merupakan krisis yang dialami akibat dari bencana tsunami yang terjadi pada penghujung tahun 2018. Warta (2017:142) mendefinisikan krisis sebagai berikut: Krisis berbeda dengan isu dan dapat diartikan sebagai resiko akut terhadap reputasi, krisis terjadi secara tiba-tiba menyebabkan pengawasan intens dan menempatkan organisasi dalam sorotan untuk segala hal yang salah. Di sisi lain seiring dengan kemajuan teknologi media dengan kemajuan teknologi media dengan jejaring internetnya, penyebaran suatu informasi akan mudah dan cepat tersebar apalagi mengenai informasi krisis dari suatu perusahaan (Choerunnisa \& Nugraha, 2020:138).

Saat ini tim satgas penanggulangan bencana masih tetap beroperasi di PT. BWJ, hal ini dikarenakan kawasan wisata Tanjung Lesung masih dalam proses pemulihan pasca tsunami 2018. Kunjungan wisatawan yang belum normal dan adanya pandemi covid-19, membuat tim satgas penanggulangan bencana harus tetap melakukan perencanaan guna meningkatkan 
kembali kunjungan wisata tanpa ada trauma yang dirasakan, didukung juga dengan strategi komunikasi sebagai tindakan komunikasi untuk menyampaikan informasi terkait kawasan wisata Tanjung Lesung. berdasarkan penjabaran diatas penulis bertujuan mengetahui serta mendeskripsikan bagaimana perencanaan dan tindakan komunikasi yang dilakukan Satgas Penanggulangan Bencana PT. BWJ pasca tsunami 22 Desember 2018 di objek wisata Tanjung Lesung.

\section{Literature Review}

\subsection{Manajemen Krisis}

Perusahaan memiliki peran dalam sebuah krisis untuk membentuk persepsi masyarakat. Sikap publik pada umumnya terhadap perusahaan cenderung lebih negatif saat krisis. Krisis bagi perusahaan merupakan sebuah kejadian buruk yang tidak dapat diprediksikan, sebuah krisis didefinisikan Argenti (2010:301) sebuah malapetaka yang dapat muncul secara alami atau sebagai hasil dari kesalahan, intervensi, atau bahkan niat jahat manusia. Krisis dapat meliputi kehancuran nyata, seperti perusakan jiwa atau asset, atau kehancuran tak berwujud, seperti kehilangan kredibilitas atau kerusakan reputasi lain dari suatu organisasi. Akibat-akibat yang terakhir mungkin merupakan hasil dari respons manajemen atas kehancuran nyata atau hasil dari kesalahan manusia. Sebuah krisis biasanya memiliki dampak keuangan actual atau potensial yang signifikan pada sebuah perusahaan dan biasanya memengaruhi konstituen di dalam lebih dari satu pasar.

Butterick (2014:72) menjelaskan krisis dalam suatu bisnis terjadi ketika nilai penjualan jatuh dan keuntungan berkurang. Warta (2017:142) mendefinisikan krisis sebagai berikut: krisis berbeda dengan isu dan dapat diartikan sebagai resiko akut terhadap reputasi, krisis terjadi secara tiba-tiba menyebabkan pengawasan intens dan menempatkan organisasi dalam sorotan untuk segala hal yang salah.

Manajemen krisis berorientasi pada masa depan, berupaya mengantisipasi dan menyiapkan diri untuk setiap kemungkinan peristiwa yang terjadi yang dapat mengacaukan hubunganhubungan yang penting dengan khalayaknya, seperti yang dijelaskan oleh Butterick (2014:74) bahwa manajemen krisis adalah respon terencana dari suatu perusahaan untuk menghadapi suatu krisis, yang harus dilaksanakan secara efektif dan tepat waktu, manajemen krisis melibatkan perencanaan dan tindakan koordinasi untuk mencegah terjadinya eskalasi krisis.

Dalam hal ini yang penting dari sebuah perencanaan dan tindakan koordiasi yang dimaksud adalah perencanaan krisis komunikasi, bagaimana suatu perusahaan merespon, seberapa cepat respon tersebut dan bagaimana perusahan berkomunikasi dan pesan-pesan yang disampaikan perusahaan. Butterick (2014:75) menjelaskan elemen-elemen dalam perencanaan krisis komunikasi. Pertama, Perencanaan. Tugas perencanaan yakni mempertahankan bisnis tetap berjalan dalam rangka menjaga staf, melindungi pekerjaan, memelihara reputasi, dan menjaga kapasitas perusahaan untuk tetap beroperasi. Kedua, Tim Manajemen. Selama berlangsung krisis manajemen senior perusahaan harus tampil di depan publik, dalam situasi tersebut publik mengharapkan jawaban dan penjelasan dari petinggi perusahaan. Ketiga, Proses Komunikasi. Bagian ini membahas bagaimana operasionalisasi perencanaan ketika mulai terjadi krisis untuk pertama kalinya, dalam sebuah program yang terpetakan secara jelas akan tertera daftar tindakan yang perlu diambil beserta waktu pelaksanaannya. Keempat, Evaluasi Pasca Krisis. Pada tahap ini perencanaan komunikasi sebaiknya juga mencakup sebuah analisis yang jujur dan kritis mengenai apa yang terjadi selama krisis, disana akan terlihat bagaimana tim komunikasi melakukan respon selama situasi krisis.

Menurut Gary Kreps (dalam Kriyantono, 2015:221) menjelaskan krisis merupakan sebuah proses yang menggunakan aktivitas public relations untuk mengatasi akibat negatif, misalnya kerusakan-kerusakan yang dialami oleh organisasi. Menyebutkan public relations sebagai manajer 
krisis, dapat disimpulkan bahwa seharusnya public relations diberikan posisi yang memungkinkan berperan dalam proses merumuskan dan mengimplementasikan strategi menghadapi krisis. Kriyantono (2015:207) membagi sumber krisis menjadi dua yaitu krisis yang disebabkan langsung oleh manusia dan krisis yang disebabkan oleh faktor alam. Adapun sumbersumber krisis adalah teknologi (terjadi karena kesalahan penggunaan teknologi), konfrontasi (Terjadi karena relasi yang buruk antar individu atau organisasi), malevolence (terjadi jika seseorang atau kelompok berkeinginan menjatuhkan atau membahayakan organisasi), manajemen dan perilaku karyawan (terjadi karena kegagalan kelompok manajemen melaksanakan tanggung jawabnya), lingkungan kerja, Bencana Alam dan produksi. Terdapat dua jenis krisis yang ditimbulkan oleh produksi, yaitu (a) kredibilitas produk, krisis akibat produk dianggap tidak efektif, kredibel dan tidak memuaskan. (b) product tampering jika produk dituduh membuat konsumen meninggal, sakit, keracunan atau terluka.

Konsep mengenai definisi manajemen krisis berimplikasi dalam strategi manajemen krisis dalam kajian Public Relations. Salah satunya model strategi manajemen krisis dari (Khasali, 1995: 225-230) yang mengadaptasi model anatomi krisis Steven Fink. Pertama, tahap prodomal yang sering juga disebut warning stage karena ia memberi sirine tanda bahaya mengenai simtomsimtom yang harus segera diatasi. Mengacu pada definisi krisis, tahap ini juga merupakan bagian dari turning point bila manajemen gagal mengartikan atau menangkap signal ini, krisis akan bergeser ke tahap yang lebih serius yaitu tahap akut. Sering pula tahap prodomal sebagai tahap sebelum krisis atau precrisis. Tetapi sebutan ini hanya dapat dipakai untuk melihat krisis secara keseluruhan dan disebut demikian setelah krisis memasuki tahap akut sebagai retrospeksi. Kedua, tahap akut, yaitu tahap dimana orang mengatakan "telah terjadi krisis". Meski bukan di sini awal mulanya krisis, orang menganggap suatu krisis dimulai dari sini karena gejala yang samar-samar atau sama sekali tidak jelas itu mulai kelihatan jelas. Dalam banyak hal, krisis yang akut sering disebut sebagai the point of no return. Artinya, sekali signal-signal yang muncul pada tahap peringatan atau prodomal stage tidak digubris, ia akan masuk ke tahap akut dan tidak bisa kembali lagi. Kerusakan sudah mulai bermunculan, reaksi mulai berdatangan, dan isu menyebar luas.

Ketiga, tahap kronik. Tahap ini sering juga disebut sebagai the clean of phase atau the post mortem. Sering pula tahap ini disebut sebagai tahap recovery atau self analysis. Di dalam perusahaan, tahap ini ditandai dengan perubahan struktural baik penggantian manajemen, penggantian pemilik, memasukkan nama-nama baru sebagai pemilik atau dilikuidasi. Crisis manager harus mampu memperpendek tahap ini karena semua orang sudah merasa letih, juga pers sudah mulai bosan memberitakan kasus ini. Namun, yang paling penting adalah perusahaan harus memutuskan mau hidup terus atau tidak. Kalau ingin hidup terus tentunya ia harus sehat dan mempunyai reputasi yang baik. Tahap kronik adalah tahap yang terenyuh. Kadang-kadang dengan bantuan konsultan krisis yang handal, perusahaan akan memasuki keadaan yang lebih baik, sehingga pujian berdatangan dan penyembuhan atau resolution mulai berlangsung. Keempat, tahap Resolusi atau (Penyembuhan). Tahap ini adalah tahap penyembuhan atau pulih kembali dan tahap terakhir dari empat tahap krisis. Meski bencana besar dianggap sudah berlalu, crisis manager tetap perlu berhati-hati, karena riset dalam kasus-kasus krisis menunjukkan bahwa krisis tidak akan berhenti begitu saja pada tahap ini. Krisis umumnya berbentuk siklus yang akan membawa kembali keadaan semula atau prodomal stage.

Lebih lanjut, Nova (2012:115-122) menjelaskan krisis berdasarkan Warning Time. Berdasarkan warning time, krisis terbagi dalam dua jenis, yaitu sudden crisis dan smoldering crisis. Sudden Crisis (krisis yang terjadi secara mendadak merupakan gangguan dalam bisnis perusahaan yang terjadi tanpa peringatan dan mungkin menghasilkan berita dan berdampak pada karyawan perusahaan, investor, pelanggan, suppliers, atau masyarakat luas, relasi bisnis, pemegang hak 
paten atau aset-aset bisnis lain, pendapatan perusahaan, laba bersih, harga saham dan reputasi perusahaan. Sudden crisis dapat terjadi karena hal-hal berikut:

a. Suatu kecelakaan yang berkaitan dengan bisnis yang mengakibatkan property rusak dan mengganggu operasional bisnis secara normal.

b. Kematian atau penyakit atau luka serius dari manajemen, karyawan, pemborong, pelanggan, pengunjung dan lain-lain, sebagai hasil dari suatu kecelakaan yang terkait dengan bisnis perusahaan.

c. Kegagalan atau kekacauan pada momen-momen terakhir untuk mengakhiri proses bisnis, transaksi penjualan, perjanjian kerjasama atau karena ketidakmampuan seorang eksekutif.

d. Penggunaan bahan kimia yang penuh resiko atau bahan-bahan berbahaya lain di dalam suatu lingkungan

e. Kecelakaan yang menyebabkan gangguan layanan

f. Pengurangan yang signifikan di dalam fungsi-fungsi atau jasa penting yang diperlukan untuk melakukan suatu bisnis.

g. Setiap bencana alam yang mengganggu operasional dan membahayakan karyawan

h. Human eror yang tak terduga atau gangguan tenaga kerja

i. Kekerasan/kekejaman ditempat kerja yang melibatkan para anggota karyawan/keluarga atau para pelanggan.

Smoldering crisis digambarkan pada setiap masalah bisnis serius yang tidak biasa terjadi di dalam perusahaan. Jika diketahui publik, krisis ini dapat menimbulkan pemberitaan negatif di media. Selain itu, krisis juga akan membawa konsekuensi kerugian, pembayaran denda, penalti, akibat hukum, biaya di luar budget dan biaya lainnya. Smoldering crisis dapat terjadi karena masalah internal yang tidak teridentifikasi sejak awal; investigasi dari badan pemerintah (KPK, Kepolisian, Kejaksaan dan lain-lain) dan indikasi tindakan hukum yang merugikan perusahaan; karena masalah dengan pelanggan karena buruknya manajemen perusahaan.

\subsection{Penanggulangan Bencana}

Mitigasi bencana merupakan serangkaian upaya untuk mengurangi resiko bencana, baik melalui pembangunan fisik maupun penyadaran dan peningkatan kemampuan menghadapi ancaman bencana. Menurut Wanto (2010:12) penanganan bencana harus dilakukan jauh sebelum bencana terjadi dan juga setelah terjadinya bencana, ada beberapa tahapan dalam penanggulangan bencana yaitu meliputi kegiatan pra bencana (pencegahan, kesiapsiagaan, mitigasi), tanggap darurat dan pasca bencana atau pemulihan (rehabilitasi, rekonstruksi).

\subsubsection{Pra Bencana}

Bencana hampir seluruhnya datang mendadak, oleh karena itu perlu mempersiapkan segala sesuatu yang diperlukan apabila terjadi musibah. Apalagi pada daerah yang tidak terduga akan terjadi bencana, karena tidak termasuk daerah rawan bencana sebab sudah puluhan atau ratusan tahun tidak pernah ada bencana didaerah tersebut. Tahap ini dapat dilakukan dari pencegahan, kesigapan dan mitigasi.

\subsubsection{Tanggap Darurat (response)}

Penanganan saat terjadi bencana adalah semua kegiatan yang dilakukan Ketika bencana melanda, yang tujuannya adalah menyelamatkan korban manusia dan harta benda. Meliputi kegiatan evakuasi korban ke tempat penampungan sementara, penyelenggaraan dapur umum, distribusi atau penyaluran bantuan dalam bentuk pangan, sandang, obat-obatan, bahan bangunan, peralatan ekonomis-produktif (seperti alat pertanian dan pertukangan) serta uang 
sebagai modal awal hidup pasca bencana, pendataan korban dan jumlah kerugian material (harta benda).

\subsubsection{Pasca Bencana (Pemulihan/ recovery)}

Bantuan kemanusiaan, rehabilitasi dan rekonstruksi adalah segala bentuk kegiatan yang dilaksanakan setelah terjadinya bencana, untuk secara berurut menyelamatkan nyawa manusia dan memenuhi kebutuhan kemanusiaan yang mendesak, memulihkan kegiatan normal dan memulihkan infrastruktur fisik serta pelayanan masyarakat, pembangunan hunian sementara, penyebaran informasi publik, pendidikan kesehatan dan keselamatan, rekonstruksi, program konseling dan studi mengenai dampak ekonomi yang ditimbulkan akibat bencana tersebut.

\subsection{Teori Situasional}

Penelitian tentang manajemen krisis PT. Banten West Java Tourism Development dengan Studi Kasus Pasca tsunami 22 Desember 2018 Pada Objek Wisata Tanjung Lesung ini menggunakan Theory Situational of the Public atau sering disebut dengan STP teori ini dikembangkan oleh James E Grunig seorang professor public relations. Kriyantono (2015:152) menjelaskan bahwa:

"Theory Situational of the Public, dapat digunakan oleh praktisi public relations untuk mengidentifikasi dan mengelompokkan publik berdasarkan presepsi, sikap, dan perilaku publik terhadap organisasi, baik terhadap programnya, produknya, maupun ketika terjadi situasi krisis"

Berdasarkan penjabaran tersebut untuk dapat mengelola krisis Tanjung Lesung pasca tsunami 2018, PT. Banten West Java Tourism Development selaku perusahaan pengelola wisata Tanjung Lesung melakukan pengelompokan publiknya berdasarkan persepsi, sikap dan perilaku publik terhadap organisasi. Teori ini juga beranggapan bahwa publik memiliki pengetahuan (knowledge) dan kesadaran (awareness), sikap, dan perilaku tertentu terhadap organisasi.Maka dari itu, praktisi public relations harus memahami publiknya melalui perilaku komunikasi yang dilakukan oleh publiknya.

Teori situasional Grunig berupaya untuk mengidentifikasi permasalahan di sekitar publik, Grunig menyebutnya isu-isu situasional. Grunig berargumen, penelitian komunikasi lebih memperhatikan pemasaran pada produk dibandingkan publik-publik mereka (perusahaan), Ardianto (2004:232) mengatakan:

"Teori situasional mendorong pembentukan publik-publik mereka, sewaktu orang-orang mengatur transaksi dengan suatu konsekuensi pada organisasinya mereka, dan Grunig menekankan, publik-publik ini menjadi target-target optimal kampanye komunikasi."

Dalam model Teori Situasional, Grunig mengidentikasi empat macam publik secara khusus diantaranya all-issue publics atau publik aktif pada semua isu, aphatetic publics atau publik tidak memperhatikan semua isu, single-issue publics atau publik hanya aktif pada satu, atau sebagian kecil isu pokok, yang hanya memperhatikan sebagian kecil dari populasi dan hot-issue publics atau publik hanya aktif pada isu tunggal yang melibatkan orang-orang terdekatnya dalam populasi, dan diterima karena peliputan media secara luas. Berdasarkan penjabaran diatas maka dapat dikatakan bahwa PT. Banten West Java Tourism Development mengidentifikasi publiknya untuk dapat mengetahui bagaimana persepsi publik terhadap perusahaan pasca terjadinya tsunami Selat Sunda yang melanda kawasan objek wisata Tanjung Lesung.

\section{Metode}

Pendekatan yang digunakan pada penelitian ini adalah pendekatan kualitatif dengan metode studi kasus_untuk mendapatkan data peneliti mengembangkan analisis atas suatu kasus seperti komunikasi, peristiwa aktivitas ataupun proses yang terjadi dilokasi penelitian. Studi kasus sebagai rancangan penelitian yang banyak ditemukan di dalam banyak bidang khususnya 
evaluasi, dimana peneliti mengembangkan analisis mendalam atas suatu kasus (Creswell, 2016:16).

Robert K. Yin (2015:15) juga menjelaskan desain strategi penelitian studi kasus. Robert K. Yin beranggapan bahwa karakter umum desain penelitian berperan sebagai latar untuk memikirkan desain yang spesifik bagi studi kasus. Peneliti dalam penelitian tentangManajemen Krisis Satgas Penanggulangan Bencana PT. Banten West Java Tourism Development (Studi kasus Pasca Tsunami 22 Desember 2018 di Objek Wisata Tanjung Lesung), menggunakan metode studi kasus tunggal holistic karena dalam penelitian ini peneliti mengkaji komunikasi umum yang dilakukan pihak perusahaan dalam proses mengelola krisis Tanjung Lesung pasca tsunami diakhir tahun 2018 sehingga dapat meningkatkan kembali jumlah kunjungan wisatawan.

Teknik pengumpulan data dengan menggunakan wawancara. Wawancara adalah percakapan antara periset sebagai seseorang yang berharap mendapatkan informasi dan informan sebagai seseorang yang diasumsikan mempunyai informasi penting tentang suatu objek (Berger, 2000:111). Peneliti melakukan wawancara dengan menggunakan jenis wawancara semistruktur, dimana pada pelaksanaannya peneliti mempunyai daftar pertanyaan tertulis tetapi memungkinkan untuk menanyakan pertanyaan-pertanyaan secara bebas (Kriyantono, 2020:291) Pada pemilihan informan peneliti menggunakan teknik purposive sampling, dengan mempertimbangkan sumber data/informan yang akan dituju adalah sumber data/informan yang paling menguasai informasi yang dibutuhkan peneliti. Informan yang yang peneliti gunakan berjumlah 5 orang, yaitu Direktur Operasional PT. Banten West Java Tourism Development (BWJ), General Manager Project Development PT. Banten West Java Tourism Development (BWJ), Administrasi Kawasan Wisata dari PT. Banten West Java Tourism Development (BWJ), Masyarakat sekitar kawasan objek wisata Tanjung Lesung dan Pengunjung kawasan objek wisata tanjung lesung.

Pada saat wawancara peneliti menggunakan alat bantu seperti recorder, pulpen, blocknote, dan daftar pertanyaan. Peneliti menyadari keterbatasan jumlah informan yang digunakan dan masih banyaknya kelemahan pada penelitian ini, semoga peneliti yang lain dapat melanjutkan dan menyempurnakan penelitian ini.

Teknik pengumpulan data selanjutnya adalah teknik observasi yang merupakan kemampuan seseorang untuk menggunakan pengamatannya melalui hasil kerja pancaindra mata dibantu dengan panca indra lainnya (Bungin, 2007:118). Peneliti menggunakan observasi non-partisipan, dimana peneliti datang ke lokasi wisata Tanjung Lesung yang terkena tsunami dan mengamati kondisi pasca tsunami, namun peneliti tidak ikut terlibat dalam kegiatan pengelolaan krisis yang dilakukan tim satgas penanggulangan bencana PT BWJ. Peneliti mengamati media komunikasi yang digunakan dalam pengelolaan krisis, mengamati kondisi di lokasi tsunami yang banyak sekali tempat usaha warga yang tutup dan terkena dampak tsunami, begitu mengamati pengunjung yang datang selama tiga hari untuk mengetahui antusias wisatawan untuk datang ke Tanjung Lesung pasca tsunami 2018.

Selain itu teknik pengumpulan data yang digunakan peneliti adalah dokumentasi. Dokumentasi ini bertujuan untuk menggali data - data masa lampau secara sistematis dan objektif (Bungin, 2007:308). Pada metode dokumentasi peneliti dapat menggunakan dokumen sebagai sumber informasi dalam menginterpretasikan data observasi (Kriyantono, 2020:118). Pada penelitian ini teknik dokumentasi membantu peneliti untuk mengumpulkan data terkait pengelolaan krisis yang dilakukan tim satgas penanggulangan bencana PT BWJ. Adapun dokumen yang digunakan oleh peneliti seperti Kliping berita tsunami Tanjung Lesung 2018, Foto-Foto kegiatan pasca kejadian, data yang tersimpan pada media sosial, dan jurnal-jurnal terkait komunikasi bencana.

Setiap temuan data harus dicek keabsahannya agar penelitian dapat dipertanggungjawabkan, maka peneliti menggunakan teknik triangulasi sumber dimana peneliti mendeskripsikan 
pandangan yang satu maupun pandangan yang berbeda ataupun pandangan yang didapat oleh peneliti di lapangan.

Skema 1. Analisis Data Kualitatif Dari Data Hingga Interpretasi

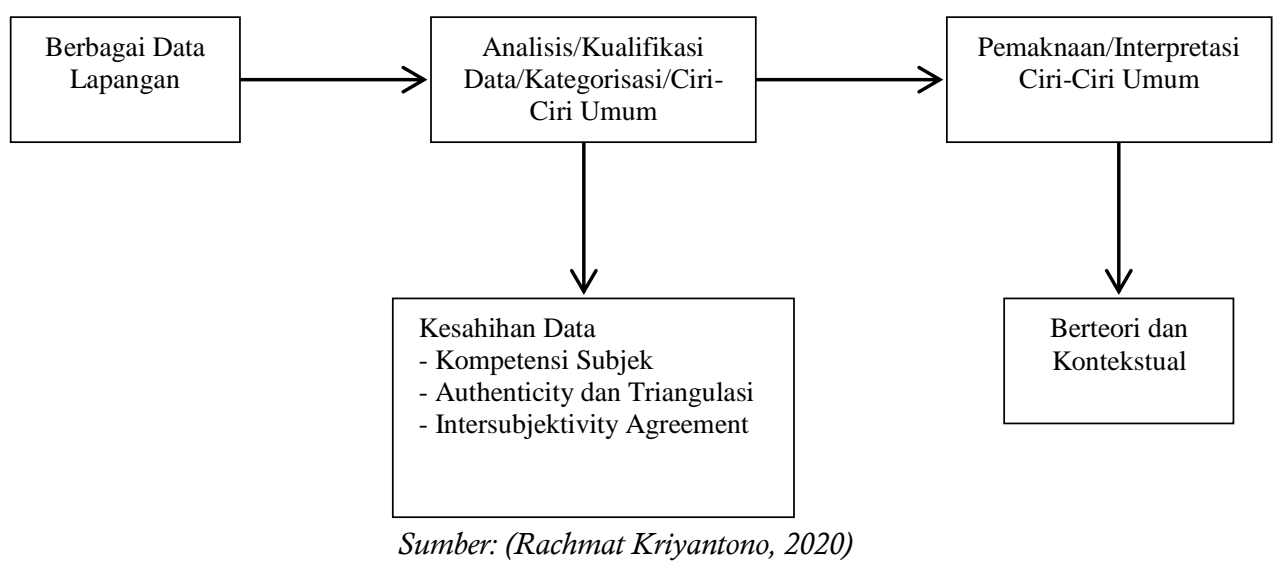

Berdasarkan Skema 1 menjelaskan data kualitatif dianalisis dari data yang berhasil dikumpulkan oleh peneliti. Analisis data adalah proses mengorganisasikan dan mengurutkan data dalam pola, kategorisasi dan satuan uraian dasar, sehingga dapa ditemukan tema untuk mengorganisasikan data yang terkumpul yang terdiri dari catatan lapangan dan interpretasi peneliti, gambar, foto, dokumen berupa laporan, artikel (Moleong, 2013:280-281). Setelah dikategorisasikan dan diklasifikasikan peneliti membangun interpretasi terhadap data yang didapat.

\section{Hasil dan Pembahasan}

\subsection{Perencanaan Satgas Penanggulangan Bencana PT. BWJ}

Krisis yang dialami oleh PT. Banten West Java Tourism Development merupakan kriris yang disebabkan oleh bencana alam tsunami. Becana tidak dapat dihindari dan akan menimbulkan krisis ketika banyak korban yang berjatuhan, selain itu bencana tsunami memberikan rasa trauma yang berbekas pada setiap wisatawan yang berkunjung pada kawasan wisata. PT BWJ melalui tim satgas penanggulangan bencana merespon kejadian tsunami dengan melakukan perencanaan yang terencana untuk menghadapi krisis, sebagai pengelola utama kawasan wisata Tanjung Lesung tim satgas penanggulangan bencana PT. BWJ harus mengedepankan rasa empati atas apa yang terjadi pasca tsunami menerjang.

Respon rencana awal memberikan informasi yang akurat, cepat dan jelas, agar masyarakat mengetahui keadaan di lokasi kejadian. Mengadaptasi model anatomi krisis Steven Fink PT Banten West Java Tourism berada pada tahap akut, dimana mulai terbentuk situasi krisis yang timbul pasca bencana tsunami, sedangkan bila dilihat berdasarkan Warning Timetermasuk pada jenis krisis yang terjadi secara mendadak (sudden crisis) bencana tsunami datang secara tiba-tiba tanpa peringatan dan menghasilkan berita yang berdampak pada karyawan perusahaan, masyarakat luas stakeholder begitu pun reputasi perusahaan.

Tim khusus satgas penanggulangan bencana yang dipimpin langsung oleh Direktur Operasional Kunto Wijaya sebagai pemimpin lapangan menyadari berada pada masa krisis akut pasca tsunami dan tidaklah mudah bagi perusahaan, disaat bersamaan pihak PT. Banten West Java Tourism Development tidak sama sekali melakukan PHK kepada para karyawannya, sehingga pihaknya harus mengeluarkan dana mencapai Rp.4.000.000.000. Keputusan perusahaan dalam memilih Direktur operasional sebagai pimpinan lapangan merupakan keputusan yang sejalan dengan elemen-elemen perencanaan kriris, selama berlangsung krisis maupun proses pemulihan kriris manajemen senior perusahaan harus tampil didepan untuk 
melindungi karyawan, perusahaan dan memelihara reputasi, selain itu situasi kriris membuat publik mengharapkan jawaban dan penjelasan dari petinggi perusahaan. Seperti yang diungkapkan informan:

"kita merupakan titik tumpu pariwisata bagi Kabupaten maupun Provinsi, sehingga kita harus mampu menjadi pioner untuk bangkit. Nah semua itu kita lakukan dengan manajemen dan tim khusus yang sudah di buat oleh Pak Kunto sebagai direktur operasional, yaitu tim satgas penanggulangan bencana yang dibentuk untuk mengatasi masalah yang muncul pasca tsunami kemarin, dengan pembangunan recovery, pembangunan sarana fisik yang rusak segala macam" (Indra Bastian, Wawancara, 12 November 2020).

Tanjung Lesung menjadi menjadi titik tumpu pariwisata yang menjadikan Tanjung Lesung sebagai wisata unggulan di Provinsi Banten, akibat bencana tsunami yang meluluh lantahkan kawasan wisata ini membuat banyak pihak merasakan kerugian dan kesedihan. Selain itu mengembalikan kembali kepercayaanmasyarakat untuk berwisata ke Tanjung Lesung itu aman. Pada tahap kris kejadian bencana alam seperti ini diperlukan kerja keras pasca tsunami Selat Sunda sebagai usaha yang ditempuh dalam mengembalikan kepercayaan pihak luar, khususnya para wisatawan domestik dan mancanegara serta mengembalikan citra Tanjung Lesung sebagai salah satu destinasi wisata yang aman dan nyaman untuk dikunjungi (Oktarini\& Atmadi, 2020:29).

Ketika suatu isu berhembus dan krisis terjadi, suatu daerah tujuan wisata harus segera melakukan komunikasi yang cepat dan efektif kepada berbagai pihak terkait, karena masyarakat sangat memerlukan informasi yang akurat, cepat dan tepat tentang isu tersebut (Putra, 2008:43). Hal ini yang yang akhirnya mendorong PT. BWJ yang di pimpin oleh Kunto Wijaya sebagai Direktur Operasional dan Pemimpin Lapangan dalam Tim khusus Satgas Penanggulangan Bencana membentuk Tim Komunikasi khusus dan Media Center.

\subsection{Membuat Tim Komunikasi Khusus dan Media Center}

Tim satgas penanggulangan bencana melakukan mitigasi bencana memberikan kemampuan dalam menghadapi bencana dan mengurangi resiko bencana, dalam pelaksanaannya penangganan bencana dapat dilakukan pada saat tanggap darurat maupun pemulihan. Pasca bencana tsunami merupakan tahap pemulihan bagi PT BWJ, maka tim satgas penanggulangan PT BWJ membuat tim komunikasi khusus untuk menyampaikan informasi yang terarah, terukur dan dapat dipertanggungjawabkan yang disampaikan kepada publiknya, teori yang digunakan sebagai paduan pada penelitian ini yaitu teori situasional of the public dimana perusahaan mengidentifikasi publiknya berdasarkan sikap dan perilaku komunikasi dari publik terhadap organisasinya, teori ini menjelaskan bahwa publik memiliki pengetahuan (knowledge) dan kesadaran (awareness), sikap dan perilaku tertentu terhadap organisasinya.

Semua perlakuan publik terhadap perusahaan sesuai dengan situasi yang dihadapi dan bersifat dinamis. Saat bencana tsunami terjadi maupun setelah bencana tersebut semua publik akan aktif mencari tahu informasi terkait bencana tsunami di Tanjung Lesung, respon publik pada saat terjadi tsunami merasa tidak percaya akan berwisata ke pantai dan merasa takut untuk berwisata ke Tanjung Lesung, selain itu banyaknya respon dimana PT BWJ tidak memperhatikan keamanan dalam berwisata. Tim komunikasi khusus dan media center yang di bentuk oleh satgas penanggulangan bencana memiliki fungsi untuk mengatur arus informasi dan sumber pemberitaan satu arah, terukur, apa adanya, dan dapat dipertanggungjawabkan.

PT. Banten West Java Tourism Development menyadari bahwa dalam situasi krisis publik banyak mengharapkan informasi terkait Tanjung Lesung, sehingga membentuk tim komunikasi khusus menjadi salah satu cara yang dilakukan oleh tim manajemen, seperti yang diungkapkan oleh informan sebagai berikut: 
"Setelah kejadian 22 desember kemarin hal pertama yang kita lakukan adalah kita bikin media center atas arahan pak kunto, kenapa, karena banyak wartawan dari lokal, nasional, termasuk dari komunitas atau partai, nah kita Mau kalo sumber pemberitaan ini keluar dari satu pintu, bahkan dari BWJ sendiri menunjuk satu orang untuk menjadi sumber beritanya yaitu pak hendra, nah jadi media center yang kita bentuk diawal ini yaitu media sosial kita yang menjadi sumber pemberitaan satu arah, terukur, apadanya, dan yang terpenting dapat dipertanggungjawabkan" (Indra Bastian, Wawancara, 12 November 2020).

Pernyataan diatas menjelaskan komunikasi pada saat krisis sangat dibutuhkan dari memberikan data dengan tepat dan memberikan informasi kepada pihak yang terkena dampak. Dilihat pada komunikasi krisis bertautan erat dengan peran media massa elektronik maupun online. Media massa menjadi salah satu patner utama bagi tim komunikasi krisis sekaligus pihak yang mempublikasikan hitam putihnya fakta di lapangan dan juga perkembangan terakhir penanganan krisis (Ganiem, 2019:231). Kebiasaan publik yang selalu ingin tahu informasi mengenai krisis yang diakibatkan oleh bencana, menjadikan tim komunikasi dan media center harus tetap memberikan informasi melalui konten-konten di media sosial yang PT BWJ kelola. Di media sosial dengan keaktifan dan akses dengan waktu kapan pun, ruang untuk isu menjadi lebih luas dan mengglobal. Juga karakter database atau penyimpanan konten menyebabkan media sosial seolah-olah menjadi gudang terbuka untuk diakses kapan pun (Nasrullah, 2021:148-149).

Pada tahap tanggap darurat dilakukannya pelayanan informasi dengan tujuan memberikan tanggapan cepat sebagai saluran informasi interaktif bagi pihak-pihak yang ingin mendapatkan informasi terkait krisis kepariwisataan yaitu; pemangku kepentingan, masyarakat dan media (Suwanda, dan Widjaja, 2020:8). Tim komunikasi khusus dan media center menjadi upaya yang dilakukan oleh tim khusus satgas penanggulangan bencana PT. Banten West Java Tourism Development untuk dapat terus meng-update perkembangan kawasan wisata Tanjung Lesung kepada publik melalui media sosial Instagram miliknya di@tanjunglesung.id. Respon cepat dalam menanggapi gejala krisis yang terjadi yang dilakukan oleh satgas penanggulangan bencana PT. Banten West Java Tourism Development dalam menyampaikan informasi kepada publiknya dirasakan oleh Syifa Fauziyah sebagai masyarakat sekaligus pengunjung kawasan wisata Tanjung Lesung. Teknologi komunikasi dapat digunakan untuk mengelola krisis, dalam hal ini, media social dapat digunakan sebagai media informasi untuk meringankan krisis dengan menyampaikan berita yang tepat, sehingga public dapat mengetahui informasi yang benar, (Mohamad, B., \& Bungin, 2020:201).

\subsection{Bekerjasama dengan BMKG Pusat dan Perum Damri Serang}

Indra Bastian menjelaskan dengan mendapat perhatian dan dukungan dari pemerintah serta bekerjasama dengan BMKG dalam penyediaan alat pendeteksi bencana alam yang dipasang di sepanjang kawasan pariwisata Tanjung Lesung, bekerjasama dengan BMKG tim khusus Satgas Penanggulangan Bencana berharap upaya ini dapat mengurangi rasa trauma masyarakat dan menepis stigma buruk yang tercipta di masyarakat, sehingga masyarakat kembali memiliki rasa percaya bahwa berwisata pantai tetap aman pasca tsunami, selain itu dengan dipasangnya alat mitigasi bencana disepanjang kawasan Tanjung Lesung ini tim khusus satgas penanggulangan bencana berharap dapat menarik kembali jumlah kunjungan wisatawan ke Tanjung Lesung. Tim satgas penanggulangan bencana juga berupaya menghilangkan rasa trauma yang dialami oleh para karyawan pasca tsunami di akhir tahun 2018 dengan melakukan trauma healing, dimana tim khusus satgas penanggulangan bencana mengundang pemuka agama untuk memberikan trauma healing kepada para karyawan untuk menghilangkan trauma yang dialami karyawan. Program trauma healing dilakukan untuk memulihkan kembali mental pekerja pariwisata masyarakat ke kondisi normal (Puspitasarie, Monaby, \& Utomo, 2019:300). PT. Banten West Java Tourism Development menjelaskan berada di tahap krisis pasca tsunami tidak lantas membuat perusahaanya berada dalam keterpurukan apalagi kawasan pariwisata Tanjung Lesung 
merupakan titik tumpu pariwisata bagi kabupaten Pandeglang maupun provinsi Banten, sehingga Tanjung Lesung harus mampu menjadi pioner untuk bangkit.

PT. Banten West Java Tourism Development dalam pemasangan alat pendeteksi bencana alam yakni Earthquake Early Warning System (EEWS) merupakan sistem monitoring pendekteksi gempa bumi dari hulu yang bekerja mengukur, memproses data otomatis sehingga informasi gempa bumi dan potensinya dapat lebih cepat tersampaikan, kemudian Radar Tsunami WERA adalah alat yang terpasang di bibir pantai guna pengamatan dan pendeteksi dini potensi tsunami yang disebabkan oleh gempa bumi tektonik maupun non tektonik dengan daya jangkau $200 \mathrm{~km}$ dan Warning Receiver System (WRS) merupakan tool diseminasi yang memungkinkan sharing informasi dari computer BMKG kepada computer institusi yang kemudian informasi diteruskan melalui SMS ke 20 nomor HP yang telah didaftarkan. Kepercayaan berbagai pihak terutama pengguna objek wisata akan bertambah dengan kemampuan destinasi dalam mengendalikan bencana terjadi di wilayahnya (Yumantoko, 2019:20).

Tim Satgas Penanggulangan Bencana PT. Banten West Java Tourism Development juga melakukan perencanaan lain dalam upaya menangani krisis pasca tsunami 22 desember 2018, yaitu bekerjasama dengan Perum DAMRI Serang untuk pembukaan dua trayek baru yaitu Merak - Tanjung Lesung dan Bandara Internasional Soekarno Hatta - Tanjung Lesung, sehingga lebih memudahkan masyarakat atau wisatawan luar daerah untuk berkunjung ke wisata Tanjung Lesung. Diharapkan dapat mendongkrak kembali jumlah kunjungan wisatawan, pihak PT. Banten West Java Tourism Development beranggapan bahwa infrastruktur dan transportasi menjadi kunci utama untuk menarik kembali wisatawan berkunjung ke Tanjung Lesung, mengingat sebelumnya belum pernah ada transportasi umum yang bisa langsung masuk kawasan Tanjung Lesung. Hal ini pun disambut baik oleh pihak DAMRI sebagai perusahaan transportasi milik Negara berkewajiban untuk mendukung penuh mobilitas menuju kawasan wisata nasional dalam hal ini adalah Kawasan Ekonomi Khusus Tanjung Lesung, pemberitaan mengenai dukungan Perum DAMRI dalam upaya pemulihan Wisata Tanjung Lesung dijelaskan rute dan jadwal keberangkatan DAMRI beserta biaya yang harus dikeluarkan oleh wisatawan saat menaiki moda transportasi tersebut (Dispar.bantenprov.go.id, 2020).

Melengkapi fasilitas penunjang pengembangan pariwisata yang belum ada atau menambahkan yang sudah ada (Nana, 2020:255). Perwujudan dibukanya dua trayek jalur menuju objek wisata Tanjung Lesung tentunya dapat diharapkan meningkatkan kembali jumlah wisatawan ke pantai Tanjung Lesung, mengingat sebelum terjadinya tsunami akses dari kota menuju Tanjung Lesung belum ada transportasi umum yang langsung masuk ke kawasan Tanjung Lesung, biasanya transportasi umum dari kota hanya sampai di Desa Citeureup kemudian wisatawan harus turun dan ganti menggunakan ojek pangkalan menuju kawasan Tanung Lesung, sehingga dengan adanya transportasi umum DAMRI jurusan Merak-Tanjung Lesung dan Bandara Soekarno Hatta-Tanjung Lesung ini dapat memudahkan para wisatawan untuk berkunjung ke objek wisata Tanjung Lesung, karena rute DAMRI ini akan masuk ke dalam kawasan wisata Tanjung Lesung sehingga wisatawan bisa langsung turun di depan hotel atau area pantai Tanjung Lesung.

Penambahan fasilitas untuk memberikan kemudahan transportasi maupun infrastruktur kepada wisatawan berkunjung ke kawasan wisata Tanjung Lesung, selain itu kolaborasi dengan berbagai pihak menunjukan keseriusan manajemen PT BWJ dalam mengembalikan kembali keadaan Tanjung Lesung sebagai wisata unggulan Provinsi Banten. Pemulihan keadaan pasca tsunami membutuhkan keterbukaan dari segala pemangku kepentingan, untuk bersama-sama membuka arus komunikasi dua arah secara positive dan membantu menyebarkan segala bentuk kegiatan yang bertujuan mengembalikan kepercayaan publik melalui kana-kanal komunikasi bersama. 
Gambar 1. Dukungan DAMRI kepada Tanjung Lesung
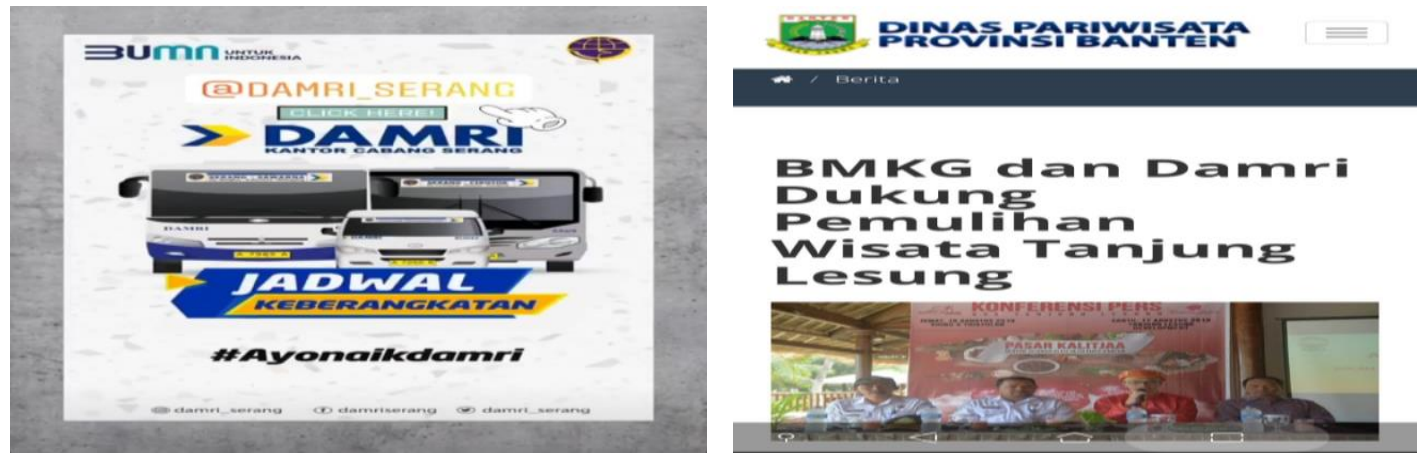

Sumber: Instagram dan Website Dispar

Gambar 1 merupakan pemberitaan di media terkait dukungan BMKG pusat dan Perum DAMRI kantor cabang Serang dalam mendukung upaya Tanjung Lesung bangkit pasca bencana alam tsunami pada 22 desember 2018. Pengembangan pariwisata adalah segala kegiatan dan usaha terkoordinasi untuk menarik wisatawan dan menyediakan semua sara dan prasarana, baik berupa barang atau jasa dan fasilitas yang diperlukan guna melayani kebutuhan wisatawan (Ratriningsing, 2017:191). PT BWJ melakukan komunikasi mengenai pembukaan trayek maupun pemasangan deteksi tsunami melalui instragram maupun website para pemangku kepentingan.

\subsection{Tindakan komunikasi Satgas Penanggulangan Bencana PT. BWJ Menangani Krisis Pasca Tsunami 2018}

Setelah melakukan perencanaan untuk memulihkan kembali kawasan wisata pasca bencana tsunami, dengan menjadikan Direktur Operasional sebagai garda depan untuk menghadapi semua publik dan menjaga keberlangsungan perusahaan. Tahap ini tetap membutuhkan proses komunikasi baik untuk memberikan informasi dilokasi bencana maupun membuat strategi promosi pariwisata. Melihat pariwisata saat telah menduduki posisi nomor dua sebagai penyumbang devisa terbesar di Indonesia Pencapaian tersebut bukanlah sesuatu yang tidak disengaja, beberapa strategi dilakukan oleh pemerintah untuk mencapai posisi tersebut salah satunya strategi pemasaran pariwisata (Wicaksono, 2018:1). Dalam tindakan komunikasi pasca bencana tsunami tim khusus Satgas Penanggulangan Bencana PT. Banten West Java Tourism Development melakukan beberapa kegiatan yang bermaksud untuk mempromosikan kembali Tanjung Lesung sebagai destinasi wisata, diantaranya:

\subsubsection{Membuat Program Pemulihan}

Komponen utama pariwisata menurut Johnpaul terdiri dari; (1) aksesibilitas, (2) transportasi, dan (3) atraksi (Bungin, 2015:86). Tim khusus Satgas Penanggulangan Bencana PT. Banten West Java Tourism Development membuat program-program atau event-event yang bertujuan untuk menarik kembali minat masyarakat untuk berkunjung ke wisata Tanjung Lesung, sehingga diharapkan melalui event-event ini pihaknya dapat mendongkrak kembali jumlah wisatawan yang datang berkunjung. Event menjadi sebuah atraksi hiburan dan rekreasi yang dapat dilihat oleh wisatawan, event menjadi salah satu alat pemasaran dalam pariwisata. Tindakan komunikasi diperlukan untuk melakukan komunikasi pemasaran mengenai destinasi wisata, aksesbilitas, dan mengajak para stakeholder baik sdm kepariwisataan untuk sama-sama membangun kembali kawasan wisata yang terkena bencana.

Turut menopang ekonomi masyarakat sekitarnya, PT. Banten West Java Tourism Development menyadari bahwa pihaknya tidak dapat berdiri sendiri, sehingga kehadiran 
komunitas-komunitas yang datang pasca terjadinya tsunami menjadi salah satu cara untuk tim satgas penanggulangan bencana PT. Banten West Java Tourism Development membawa perusahaannya keluar dari masa krisis. Bagi daerah pasca bencana, komunikasi antar elemen masyarakat diperlukan dalam upaya pemulihan perekonomian dan budaya di daerah tersebut. Manusia sebagai objek di daerah wisata merupakan target pertama yang mesti dipulihkan dari trauma-trauma bencana (Suhartini\& Afriyanti, 2018:44).

Beberapa kegiatan atau event yang diselenggarakan adalah Perhelatan akbar yang dikemas dalam sebuah acara bertajuk Pasar Kalitjaa, diramaikan dengan upacara pengibaran bendera Merah Putih yang akan dilaksanakan secara serempak di darat (Pantai Kalicaa), laut dan udara oleh komunitas warga Badui, keluarga besar Tanjung Lesung, kelompok atlit kayak, paddle board, serta paramotor. Selain itu ada festival tanjung lesung yang diselenggarakan di bulan September di setiap tahunnya, ada juga bodur festival, dan yang terbaru tanjung lesung baru saja mengadakan Tropical Sprint Rally Open Championship 2020 Badak Circuit Tanjung Lesung Resort yang diselenggarakan pada 17-18 Oktober 2020. Tropical Sprint Rally Open Championship 2020 merupakan event yang di prakarsai Tanjung Lesung Resort \& Hotel bekerjasama dengan bintang Automotive sebagai penyelenggara event dibawah naungan IMI Banten.

Selain event-event di atas satgas penanggulangan bencana PT. Banten West Java Tourism Development juga membuat program Tanjung Lesung Experience, program ini adalah program yang dibuat untuk membuat pengunjung merasakan kegiatan pariwisata apa saja yang ada di objek wisata Tanjung Lesung, seperti yang disampaikan oleh informan sebagai berikut:

\begin{abstract}
"program Tanjung Lesung Experience adalah program untuk membuat pengunjung merasakan kegiatan pariwisata yang ada di Tanjung Lesung, supaya mereka suka dulu, terutama yang orientasinya ke yang membuat mereka lebih sehat, lebih sadar dengan kesehatan, kita tawarkan bersepeda, makanan yang fresh, polapola kehidupan yang lebih sehat seperti itu yang kita kenalkan, water sport, waktu itu juga kita membuat brosur festival, kita undang komunitas-komunitas kesehatan, karena saat ini kita di tuntut melakukan gaya hidup yang sehat, dan gaya hidup pesisir Tanjung Lesung sangat mendukung untuk membuat orang lebih sehat." (Hendra, Wawancara, 11 November 2020).
\end{abstract}

Dari sekian banyak event-event atau program pemulihan yang dilakukan oleh Tim khusus satgas penanggulangan bencana PT. Banten West Java Tourism Development untuk keluar dari masa krisisnya, Indra Bastian menjelaskan bahwa Tanjung Lesung Experience menjadi program yang digadang-gadangkan dapat menarik lebih banyak lagi jumlah kunjungan ke objek wisata Tanjung Lesung.

Gambar 2. Kegiatan/Event Selama Tahun 2019 (Pemulihan Pasca Tsunami)
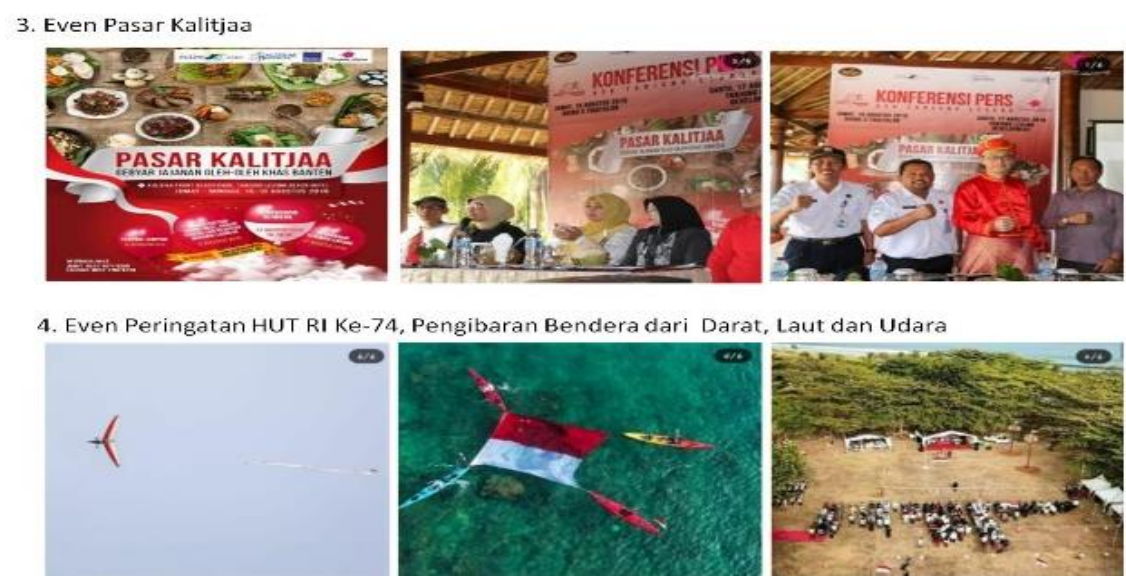

Sumber : $P T B W J$

Gambar 2 merupakan hasil dokumentasi kegiatan atau Event yang diselenggarakan oleh PT. Banten West Java Tourism Development dalam upaya meningkatkan kembali jumlah kunjungan 
wisatawan ke Tanjung Lesung sehingga diharapkan dapat membawa PT. Banten West Java Tourism Development keluar dari masa krisis pasca tsunami yang menerjang kawasannya.

Tim khusus Satgas Penanggulangan Bencana PT. Banten West Java Tourism Development beranggapan upayanya dalam mendongkrak Kembali kunjungan wisatawan ke Tanjung Lesung melalui Event-event yang dibuatnya belum berjalan sesuai dengan apa yang diinginkan, ini dapat dilihat dari grafik kunjungan wisatawan ke Tanjung Lesung sebelum dan sesudah terjadinya tsunami. Dimana pada data grafik tersebut kawasan objek wisata Tanjung Lesung mengalami jumlah pnurunan kunjungan yang sangat signifikan di tahun 2019 yaitu pasca terjadinya sunami Selat Sunda pada 22 Desember 2018 yang telah menelan banya korban jiwa dan menciptakan stigma burukdi masyarakat tentang berwisata pantai menjadi tidak aman.

Pada data jumlah kunjungan wisatawan Tanjung Lesung tahun 2017 sampai dengan 2019 jika peneliti amati mengalami penurunan yang sangat signifikan di tahun 2019 yakni, pasca tsunami 22 Desember 2018, seperti pada bulan November 2018 sebelum terjadinya bencana alam tsunami jumlah kunjungan wisatawan ke Tanjung Lesung mencapai 806.056 kunjungan, sedangkan pada bulan November tahun 2019 pasca bencana alam tsunami kunjungan wisatawan ke Tanjung Lesung hanya 510.458 kunjungan wisatawan. Dilihat dari jumlah kunjungan wisatawan tersebut maka dapat dikatakan bahwa di tahun 2019 pasca tsunami Tanjung Lesung belum mampu meningkatkan kembali jumlah kunjungannya.

Gambar 3. Tropical Sprint Rally Open Championship 2020 Badak Circuit Tanjung Lesung Resort

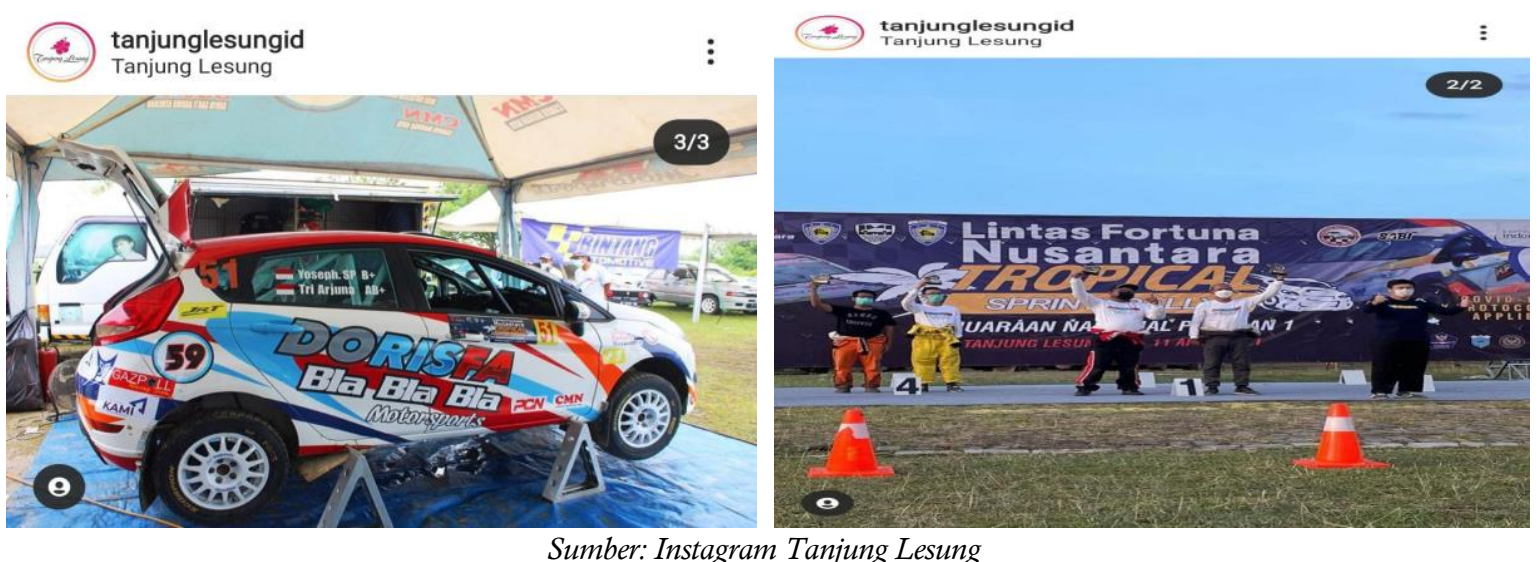

Gambar 4.3 Tropical Sprint Rally Open Championship 2020 Badak Circuit Tanjung Lesung Resort yang diselenggarakan pada 17-18 Oktober 2020. Tropical Sprint Rally Open Championship 2020 merupakan event yang di prakarsai Tanjung Lesung Resort \& Hotel bekerjasama dengan bintang Automotive sebagai penyelenggara event dibawah naungan IMI Banten.

Program-program yang telah dijalankan oleh tim khusus Satgas Penanggulangan Bencana PT. Banten West Java Tourism Development dalam upaya meningkatkan kembali jumlah kunjungan dan keluar dari masa krisis pasca tsunami dianggap belum memberikan hasil yang begitu signifikan di tahun 2019, sehingga pihak manajemen menggunakan testimoni dari pengunjung serta memanfaatkan promo dan iklan di media sosial untuk mendongkrak kembali jumlah kunjungan wisatawan ke Tanjung Lesung, seperti yang diungkapkan oleh infroman kepada peneliti sebagai berikut:

"yang harus selalu kita lakukan adalah membagikan informasi melalui digital media, facebook, Instagram, twitter atau website kita update terus apa yang kita lakukan pasca tsunami, banyak pariwisata di sepanjang anyer yang tidak bisa bangkit karena satu dan lain hal tapi Tanjung Lesung harus bangkit karena ribuan orang bergantung pada kawasan ekonomi khusus ini, jadi program-program yang kita buat kita bagikan informasinya melalui digital media secara massa." (Indra Bastian, Wawancara, 12 November 2020). 


\subsubsection{Repost Testimoni dari pengunjung dan Celebrity Endorsment}

Menyadari bahwa banyak pihak yang bergantung pada objek wisata Tanjung Lesung, tim khusus satgas penanggulangan bencana PT. Banten West Java Tourism Development tidak hanya mengandalkan satu cara dalam upaya meningkatkan kembali jumlah kunjungan wisatawan ke daerahnya. Pemanfaatan media sosial menjadi salah satu cara yang dianggap memberikan banyak pengaruh dalam meningkatkan jumlah kunjungan dan menghapus stigma buruk yang tercipta di masyarakat pasca tsunami 22 desember 2018.

Melalui akun resmi media sosial miliknya di @TanjungLesungid pihak PT. Banten West Java Tourism Development selaku pengelola utama ingin menyampaikan pesan kepada masyarakat bahwa berwisata pantai sudah aman, dengan merepost testimoni-testimoni atau celebrity endorsment dari orang-orang yang memiliki pengaruh, yang kemudian akan diletakkan di hightlite/sorotan akun Instagram miliknya, sehingga dapat di akses oleh siapapun yang ingin mengetahui bagaimana perkembangan terkini kawasan wisata Tanjung Lesung, Dengan begitu masyarakat atau publiknya dapat melihat secara nyata bagaimana perkembangan kondisi objek wisata Tanjung Lesung pasca tsunami 22 desember 2018.

Gambar 4. Celebrity Endorsment yang diposting di akun Instagram
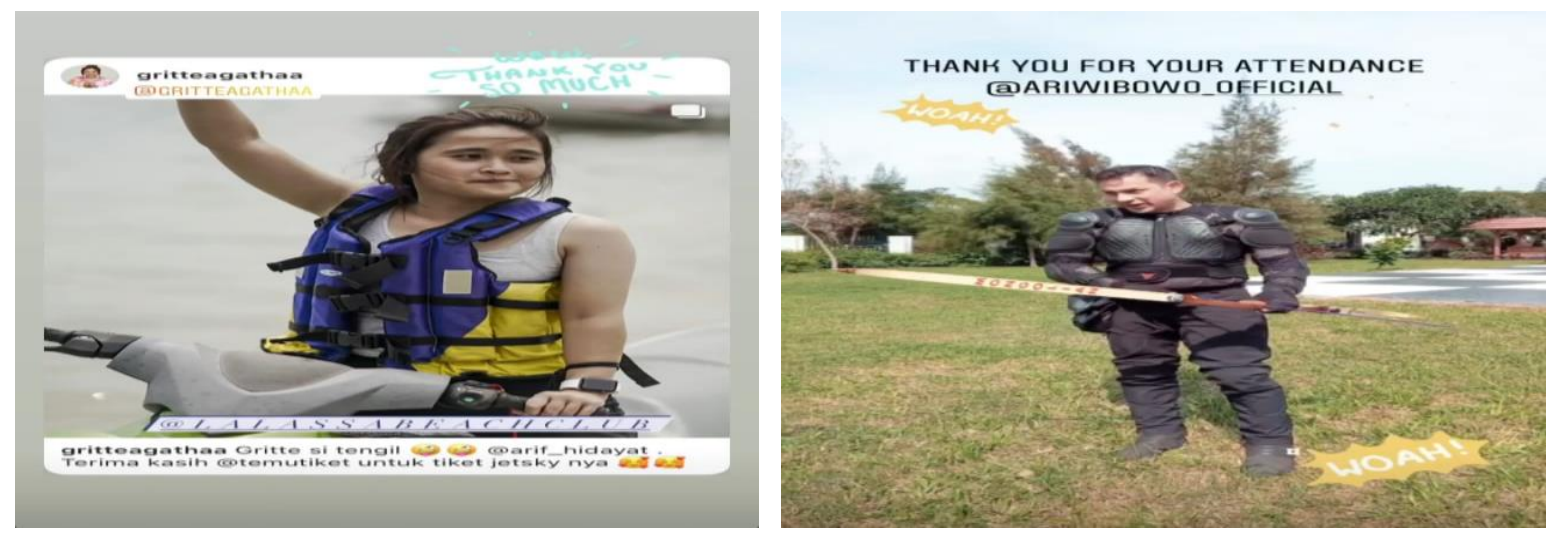

Sumber: Instagram Tanjung Lesung

Gambar 4.4 merupakan dokumentasi endorsement dari orang yang memiliki pengikut yang banyak dan berpengaruh di media sosialnya, yang kemudian di repost dan diletakan di akun Instagram resmi milik Tanjung Lesung, dengan tujuan menyampaikan pesan ke masyarakat bahwa wisata Tanjung Lesung sudah aman untuk di kunjungi, sehingga Tim khusus satgas penanggulangan bencana PT. Banten West Java Tourism Development ini berharap dapat meningkatkan kembali minat kunjungan ke wisata Tanjung Lesung

Selain review, atau repost testimoni dari pengunjung dan endorsement di akun isntagramnya, wisata Tanjung Lesung pun aktif membagikan berbagai promo, dan giveaway kepada para pengikutnya di akun Instagram, atau sekedar membagikan informasi kondisi wisata Tanjung Lesung saat ini. Sebagai salah satu pariwisata yang turut menghidupi para pelaku wisata lainnya yang berada di sekitaran Tanjung Lesung, tim khusus Satgas Penanggulangan Bencana PT. Banten West Java Tourism Development tentu berharap dengan kembali meningkatnya jumlah kunjungan wisatawan secara tidak langsung juga turut kembali menghidupkan ekonomi masyarakat dan para pelaku wisata lainnya, mengingat selama pasca tsunami 2018 PT. Banten West Java Tourism Development sebagai pemilik lahan dan pengelola utama wisata Tanjung Lesung mengalami masa krisis, ekonomi masyarakat sekitarpun turut terkena dampaknya, seperti yang diungkapkan oleh informan sebagai berikut: 
"Sekarang mah sepi neng semenjak tsunami itu, dulu mah kalo mau puasa, habis lebaran apalagi rame terus jualan seharian bisa dapat 4-5 juta, duh sekaang mah boro-boro mau jual 5 liter beras juga susah neng, paling 500-800 ribu itungannya udah rame banget, soalnya tanjung lesungnya sepi" (Roji, Wawancara, 14 November 2020).

Masyarakat dan para pelaku wisata lainnya berharap PT. Banten West Java Tourism Development selaku pengelola utama wisata Tanjung Lesung, dapat terus melakukan upaya perencanaan dan tindakan yang bisa kembali meningkatkan jumlah kunjungan ke Tanjung Lesung, sehingga dapat memberikan dampak positif pada perekonomian masyarakat sekitar, seperti yang disampaikan oleh informan sebagai berikut:

"Kalau acara sekarang suka ada aja acara di tanjung lesung habis tsunami tetap ada acara hiburan kaya festival tanjung lesung juga suka ada neng, cuman tetap tidak seramai kaya dulu sebelum tsunami, mungkin orang-orang masih pada takut datang ke sini, semoga aja nanti makin banyak acaranya jadi rame lagi lah." (Roji, Wawancara, 14 November 2020).

PT. Banten West Java Tourism Development menyampaikan bahwa disaat jumlah kunjungan mulai meningkat di awal tahun 2020, juga jumlah pembangunan hotel dan fasilitas di kawasan wisata Tanjung Lesung mulai meningkat, Indonesia di serang pandemi yang juga turut memberikan dampakyang cukup besar pada pariwisata Tanjung Lesung seperti yang disampaikan oleh Kunto Wijaya Direktur Operasional PT. banten West Java Tourism Development mengatakan:

\begin{abstract}
"Oh tentu berpengaruh, pariwisata duluan yang kena, bahkan awal-awal covid kita tidak boleh terima tamu, tapi tetap sampai saat ini walaupun dilanda pandemi juga kita tidak pernah melakukan PHK kepada karyawan, karena pada saat krisis kemarin dan sekarang pandemi kita larikan karyawan ke argo bisnis dulu, minimal tanaman yang kita tanam itu untuk konsumsi kita sendiri dan itu dilakukan oleh seluruh karyawan, selama pengunjung sepi, minimal kita punya ketahanan pangan sendiri ditambah badan menjadi lebih sehat. (Kunto Wijaya, Wawancara, November 2020).
\end{abstract}

Tim khusus Satgas Penanggulangan Bencana PT. Banten West Java Tourism Development menjelaskan bahwa pihak nya sudah mulai akan bangkit dari krisis pasca tsunami yang terjadi di akhir tahun 2018, namun pandemi yang sedang menyerang hampir seluruh Negara di dunia termasuk Indonesia memberikan dampak yang cukup besar bagi kawasan wisata Tanjung Lesung.

Pada tahapan tindakan komunikasi PT. Banten West Java Tourism Development sebagai pengelola wisata Tanjung Lesung harus membahas bagaimana operasionalisasi perencanaan yang telah di buat ketika pertama kali menyadari adanya krisis pasca tsunami di akhir tahun 2018, perencanaan harus dibentuk dalam sebuah program yang terpetakan secara jelas, daftar tindakan apa yang harus diambil, beserta waktu pelaksanaanya.

Tindakan Komunikasi selain melakukan perencanaan tim satgas penanggulangan bencana PT. Banten West Java Tourism Development juga melakukan tindakan komunikasi berupa event atau kegiatan pemulihan pasca tsunami 22 desember 2018. Event atau kegiatan pemulihan tersebut diantaranya perhelatan akbar yang dikemas dalam bentuk pasar Kalitjaa, diramaikan dengan upacara pengibaran bendera merah putih yang diselenggarakan secara serempak di darat, laut dan udara oleh komunitas warga Baduy, keluarga besar Tanjung Lesung, kelompok atlit kayak, paddle boar, serta paramotor.

Selain event atau kegiatan di atas, tim satgas penanggulangan bencana PT. Banten West Java Tourism Development juga melakukan celebrity endorsment kepada orang-orang yang memiliki pengaruh, dimana orang-orang tersebut di undang untuk berlibur di Tanjung Lesung dan kemudian membagikan cerita liburannya di media sosialnya yang dapat dilihat oleh khalayak ramai, yang kemudian pihak pengelola wisata Tanjung Lesung melalui media sosial Instagram miliknya dengan nama@TanjungLesung.id akan me-repost postingan foto atau video tersebut, 
sehingga melalui kegiatan tersebut pesan yang ingin disampaikan oleh pihak pengelola bisa tersampaikan kepada publiknya bahwa berwisata pantai di Tanjung Lesung sudah aman. PT. Banten West Java Tourism Development mencoba berkomunikasi dengan publiknya melalui media sosial. Instagram sebagai media social strategies untuk promosi dan pemasaran wisata mempunyai kelebihan dan kekurangan. Kelebihan Instragram yakni aksesbilitas, efektifitas, efisiensi dan jangkauan sangat luas tanpa terbatas ruang dan waktu (Wijayanti, 2021:28).

Melakukan iklan atau promo di media sosial menjadi salah satu cara pihak satgas penanggulangan bencana PT. Banten West Java Tourism Development dalam meningkatkan kembali jumlah kunjungan, selain itu pihaknya juga giat merepost postingan testimoni dari para pengunjungnya, yang kemudian diletakan di highlight Instagram milik Tanjung Lesung sehingga dapat dilihat oleh semua orang. Hendra sebagai orang yang tergabung dalam tim satgas penanggulangan bencana PT. Banten West Java mengatakan bahwa di bandingkan dengan event, Endorse dan merepost testimoni dari pengunjung lebih memberikan pengaruh yang besar dalam peningkatan jumlah kunjungan wisatawan ke Tanjung Lesung, pihaknya mengatakan dengan melakukan endorse kepada orang yang memiliki pengaruh sebagai celebrity endorsement yang menjadi public figure, kemudian merepost testimoni dari pengunjung dapat memberikan pesan nyata kepada publik bahwa kondisi Tanjung Lesung saat ini sudah baik-baik saja.

Gambar 5. Giveaway dan Promo Instagram Tanjung Lesung

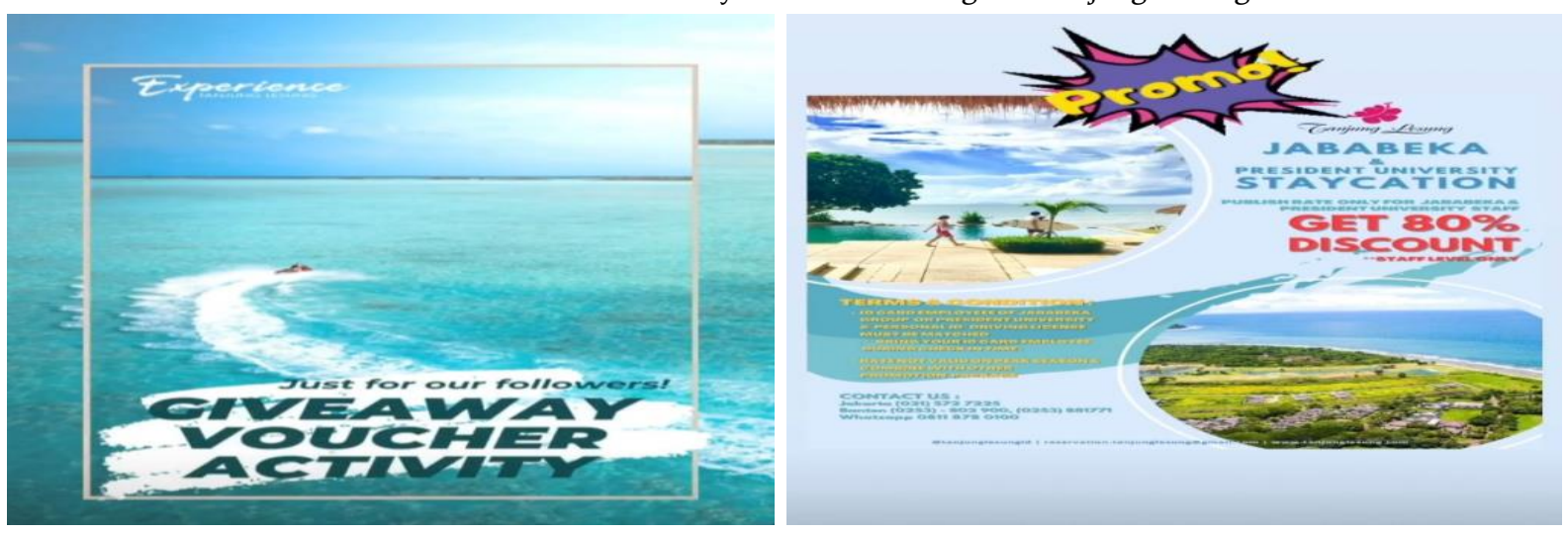

Sumber: Instagram Tanjung Lesung

Gambar 5 merupakan Giveaway dan promo yang di bagikan oleh akun Instagram Tanjung Lesung kepada para pengikutnya, sehingga tim khusus Satgas Penanggulangan Bencana PT. Banten West Java Tourism Development berharap hal ini dapat membantu menaikan kembali jumlah kunjungan serta menghilangkan stigma dan rasa trauma masyarakat untuk berwisata pantai.

Namun saat ini pihak PT. Banten West Java Tourism Development mengatakan bahwa belum $100 \%$ pulih dari masa krisis pasca tsunami pada 22 desember 2018, pada saat PT BWJ sedang semangat dalam masa pemulihan krisis pasca tsunami Indonesia diserang oleh pandemic covid-19 yang memberikan pengaruh sangat besar pada sektor pariwisata yang di paksa harus tutup dan membatasi jumlah kunjungan selama masa pandemi.

Roji sebagai pelaku wisata dan masyarakat sekitar Tanjung Lesung yang terkena dampak langsung dari peristiwa bencana alam tsunami yang menerjang kawasan Tanjung Lesung pada akhir tahun 2018 merasakan upaya pihak PT. Banten West Java Tourism Development dalam meningkatkan jumlah kunjungan, Roji mengataka bahwa selama pasca tsunami PT. Banten West Java selalu mengadakan event-event atau kegiatan yang mengundang banyak orang, namun sampai saat ini event-event atau kegiatan yang dibuat belum dirasakan dapat mengundang banyak orang dan membuat kawasannya menjadi ramai lagi, sehingga roji pun berharap pihak PT. 
Banten West Java Tourism Development dapat terus berupaya dalam pemulihan wisata Tanjung Lesung pasca tsunami pada 22 desember 2018.

\section{Kesimpulan}

Manajemen krisis satgas penanggulangan becana PT Banten West Tourism Development pasca tsunami 2018 melakukan perencanaan-perencaan guna kepeduliannya terhadap semua stakeholder yang terkait maupun masyarakat luas, dengan membuat tim komunikasi dan media center dengan menetapkan Top Manager menjadi juru bicara dalam menghadapi media ataupun masyarakat luas terkait kejelasan informasi kepada publiknya. Bencana menjadi sebuah krisis ketika banyak korban yang berjatuhan dan rusaknya semua fasilitas di sekitar lokasi kejadian dan media meliputnya, sehingga menjadi sorotan publik karena melibatkan masyarakat secara luas, maka dari itu perlu adanya mitigasi bencana untuk memulihkan kembali destinasi wisata beserta kepercayaan publik dengan memasang alat pendeteksi tsunami dan memberikan aksesbilitas bagi para wisatawan yang akan ke tempat wisata. Hal ini menjadikan kemudahan bagi masyarakat yang ingin berkunjung, tidak sampai disitu manajemen krisis perlu memikirkan tindakan komunikasi sebagai alat pemasaran dalam komunikasi pariwisata, alat komunikasi menuju pemulihan destinasi wisata dengan tujuan mendongkrak kembali wisatawan pasca bencana.

\section{Konflik Kepentingan}

Penulis menyatakan bahwa tidak memiliki konflik kepentingan dengan pihak manapun dalam penulisan artikel ini.

\section{Daftar Pustaka}

Anggarani, N. P. D., \& Arida, I. N. S. (2018). Implementasi Manajemen Krisis Pariwisata pada Kebun Raya Eka Karya Bali. Jurnal Destinasi Pariwisata, 6(1), 184-191. https://doi.org/10.24843/JDEPAR.2018.v06.i01.p28

Ardianto, E. (2004). Teori dan Metodologi Penelitian "Public Relations." Mediator: Jurnal Komunikasi, Vol. 5(No. 2), 231-241.

Argenti, P. A. (2010). Komunikasi Korporat. Jakarta: Salemba Humanika.

Berger, A. (2000). Media and Communication Research Method. New York, London: Sage Publications.

Bungin, B. (2010). Penelitian Kualitatif: Komunikasi Ekonomi, Kebijakan Publik dan Ilmu Sosial lainnya, Edisi ke-2. Jakarta: Kencana Prenada Media Group.

Bungin, B. (2015). Komunikasi Pariwisata: Tourism Communication Pemasaran Dan Brand Destinasi. Jakarta: Prenadamedia Group.

Bungin, M. B. (2020). Corporate Communication. Jakarta: Prenada Media Group.

Butterick, K. (2014). Pengantar Public Relations Teori dan Praktik. Depok: Raja Grafindo Press.

Choerunnisa, S., \& Nugraha, A. R. (2020). Strategi Manajemen Krisis Humas PLN UID JABAR Dalam Menangani Blacout Jaringan Jawa Bagian Tengah. Communirverse: Jurnal Ilmu Komunikasi, 5(2), 137-151.

Creswell, J. W. (2016). Research Design: Pendekatan Metode Kualitatif, Kuantitatif, dan Campuran. Yogyakarta: Pustaka Pelajar.

Dispar.bantenprov.go.id. (2020). Dukung Pariwisata Banten, Damri Hadirkan Rute ke Pantai Tanjung Lesung. Dinas Pariwisata Provinsi Banten. Retrieved from https://dispar.bantenprov.go.id/Berita/topic/484

Fauzi, A. R. (2020). Pengelolaan Manajemen Komunikasi Untuk Menjawab Kebutuhan Informasi Kebencanaan. Bulletin LAPAN, 7(1), 17-22.

Ganiem, L. M., \& Kurnia, E. (2019). Komunikasi Korporat Konteks Teoritis dan Praktis. Jakarta Pusat: Prenada Media Group.

Hasan, S. (2012). Strategi Krisis Public Relations Pasca Bencana. Jurnal Dialog Penanggulangan Bencana, 3(2), 67-78.

Khasali, R. (1995). Manajemen Public Relation; Konsep dan Aplikasi di Indonesia. Jakarta: Grafiti. Kriyantono, R. (2015). Public Relation Issue \& Crisis Manajemen. Jakarta: Prenada Media Group. 
Kriyantono, R. (2020). Komunikasi Publik di Era Industri 4.0. Jakarta: Kencana Media Prenada.

Meilani, N. L., \& Hardjosoekarto, S. (2020). Digital weberianism bureaucracy: Alertness and disaster risk reduction (DRR) related to the Sunda Strait volcanic tsunami. International Journal of Disaster Risk Reduction, 51, 1-11. https://doi.org/10.1016/j.ijdrr.2020.101898

Moleong, L. J. (2013). Metode Penelitian Kualitatif Edisi Revisi. Bandung: PT. Remaja Rosdakarya.

Nana, S. K. D. M. (2020). Strategi Pengembangan Pariwisata Pasca Bencana Tsunami di Kabupaten Lampung Selatan. JUrnal Birokrasi, 02(2), 243-257.

Nasrullah, R. (2021). Manajemen Komunikasi Digital Perencanaan, dan Evaluasi. Jakarta Pusat: Prenada Media Group.

Nova, F. (2012). Republic relations Knowing your public is a halfway to win the battle. Jakarta: Media Bangsa.

Nurdin, R. (2015). Komunikasi Penanggulangan Bencana. JURNAL SIMBOLIKA: Research and Learning in Communication Study, 1(1), 51-61.

Oktarini, P. W., \& Atmadi, G. (2020). Manajemen Krisis Destinasi Wisata Pasca Bencana Tsunami Selat Sunda Oleh Humas Pemerintah. Edutourism Journal Of Tourims Research, 2(2), 28-38.

Pikiran-Rakyat.com. (2019). Masih Trauma Tsunami Kunjungan Pantai Turun 60 Persen. Retrieved.

Puspitasarie, R. F., Manoby, W. M., \& Utomo, A. (2019). Pemulihan SDM Pariwisata Terdampak Bencana Pasca Bencana Gempa Bumi Lombok-Sumbawa. SABDAMAS, 1(1), 298-302.

Putra, K. D. C. (2008). Strategi Public Relations Pariwisata Bali. Ilmu Komunikasi, 5(1), 41-65.

Suhartini, E., \& Arifiyanti, J. (2018). Daerah Pasca Bencana, Daya Tarik Tersendiri Bagi Pariwisata Indonesia. Journal of Tourism and Creativity, 2(1), 35-46.

Suwanda, B. S., Sari, S. A., \& Widjaja, H. R. (2020). Strategi Manajemen Krisis Kementrian Pariwisata RI dalam menghadapi Krisis Kepariwisataan Akibat Tsunami Selat Sunda. Jurnal Sains Indonesia, 1(1), 1-17.

Tesnawati, E., \& Ratriningsih, D. (2017). Pengembangan Konsep Pariwisata Sungai Berbasis Masyarakat; Studi Kasus: Kawasan Bantaran Sungai Gadjah Wong Yogyakarta. Jurnal Arsitektur, 11(1), 189-201.

Viva.co.id. (2019). Satu Tahun Tsunami Selat Sunda, PHRI: Wisatawan Masih Trauma.

Wanto. (2010). Pola Manajemen Penanggulangan Korban Bencana Alam Pada Era Otonomi Daerah. Yogyakarta: Departemen Sosial RI Balai Besar Penelitian dan Pengembangan Pelayanan Kesejahteraan Sosial.

Warta, W. (2017). Manajemen Reputasi. Bandung: Simbiosa Rekatama Media.

Wicaksono, M. S., \& Yunitasari, D. (2018). Effektivitas Endorser Dalam Promosi Pariwisata Indonesia. Jurnal Gama Societa, 1(1), 1-8.

Wijayanti, A. (2021). Efektifitas Instagram dalam Meningkatkan Minat Kunjungan Wisatawan di Daerah Istimewa Yogyakarta. Indonesian Journal of Tourism and Leisure, 02(1), 26-39. https://doi.org/10.36256/ijtl.v2i1.138

Wulung, S. R. P., \& Abdullah, C. U. (2020). Upaya Mitigasi Pasca Tsunami Di Destinasi Pariwisata. Media Bina Ilmiah, 14(7), 2883-2894.

Yin, R. K. (2015). Studi Kasus Desain dan Metode. Jakarta: Raja Grafindo Press.

Yumantoko. (2019). Kolaborasi Para Pihak Dalam Penanganan Destinasi Wisata Terdampak Bencana Di Taman Nasional Gunung Rinjani. Jurnal Penelitian Kehutanan, 3(1), 15-28. 